\title{
SIMULASI KOMPUTER SEBAGAI ALAT PENENTU PENERANGAN ALAMI OPTIMAL PADA DESAIN SHADING DEVICE PADA RUANG ASET GEDUNG DEKANAT FT UNDIP
}

\author{
Ikhwanul Ahfadz $^{1}$ ), Erni Setyowati ${ }^{2}$, Eddy Prianto $^{2}$ \\ *) Corresponding author email : ikhwan31@gmail.com \\ 1. Astanaya.lab, Samarinda-Indonesia \\ 2. Departemen Arsitektur, Fakultas Teknik, Universitas Diponegoro, Semarang - Indonesia
}

\author{
Article info \\ MODUL vol 19 no 2, issues period 2019 \\ Doi $\quad: 10.14710 / \mathrm{mdl} .19 .2 .2019 .78-84$ \\ Received : 10 july 2019 \\ Revised : 15 july 2019 \\ Accepted : 5 november 2019
}

\begin{abstract}
Simulasi Komputer sebagai alat peminimalisir kesalahan pada desain kerap kali digunakan untuk memprediksi dalam penentuan keputusan desain. Selain Fungsi bangunan dan kebutuhan lainnya arsitek diwajibkan untuk faham akan konteks dan Kemampuan mengoptimalkan potensi iklim dari lokasi pembangunannya. Perolehan Sinar Matahari menjadi Faktor utamanya karena apabila sedikit sinar matahari yang masuk ruangannya akan kurang penerangan dan apabila terlalu banyak sinar matahari yang datang akan meningkatkan perolehan panas bangunan sehingga pengoptimalan daripada masalah tersebut merupakan kunci keberhasilan dalam sebuah perancangan. Penelitian Ini menggunakan Metode Experimental dengan mengidentifikasi lokasi, material, Fungsi ruang dan Hal-hal terkait lainnya. Tujuan penelitian ini ialah mencari shading device yang optimal sebagi perisai luar ruangan aset gedung Dekanat FT kampus Universitas Diponegoro ini. Hasil dari penlitian ini menunjukan bahwasannya dengan ada satu desain shading device yang bisa menurunkan rata-rata 33\% perolehan sinar matahari yang berpotensi besar menekan penggunaan energi Gedung Dekanat Fakultas Teknik Universitas Diponegoro Semarang.
\end{abstract}

Keywords: Shading Device; Daylighting; Simulation ; Autodesk Ecotect; Undip

PENDAHULUAN

\section{Latar Belakang}

Kemampuan untuk menjalankan simulasi adalah semestinya telah menjadi skill mendasar bagi arsitek masa kini, karena bisa memperkaya pengetahuan dan mengerucutkan kesimpulan dalam perancangan. Simulasi ini bisa menjadi bahan pengembangan dalam pembekuan nilai-nilai tertentu sehingga kemampuan bersimulasi akan mempengaruhi nilai jual daripada karya arsitektur itu sendiri. Akan tetapi semua hal yang berhubungan dengan simulasi selalu mempunyai background theory yang jelas sehingga pemahaman kepada hal tersebut tidak kalah pentingnya sebab rekomendasi algoritmik komputer dan renderasi visual membutuhkan kajian yang dalam dan bijaksana untuk mengoptimalkan keputusan dalam menyelesaikan masalah daripada perencanaan.

Usaha Konservasi energi bukanlah hal yang baru dalam perkembangan arsitektur indonesia (Pribadi \& Indarto, 2002). Usaha untuk memasukan simulasi dalam kurikulum perkuliahan juga telah banyak digalakkan (Satwiko, 2011) melalui software dialux untuk simulasi penerangan buatan ,Melakukan Perbaikan Ventilasi demi meninggikan kenyamanan ruang melalui rasio bukan efektif (Hamzah et al., 2014) dengan Software, Simulasi Komputer dengan Software Autodesk Computational Fluid Dynamics (Hamzah et al., 2014), untuk rekomendasi desain penghawaan alami dan simulasi Software Ecotect dalam meningkatkan kualitas penerangan alami bangunan (Baharuddin, 2011). Kesemua jurnal yang telah disebutkan diatas menggaris bawahi tentang kehati-hatian perancangan dalam memutuskan perancangan dan beranggapan bahwasanya keberadaan software tersebut merupakan Lompatan besar dalam meminimalisir kegagalan desain (Maulana, 2016), Tujuan Penelitian ini adalah Mencari Rekomendasi Desain yang Optimal Untuk Shading Device Luar pada Ruang Aset Dekanat FT Universitas Diponegoro.

Manusia dan Iklim

Manusia hidup dalam alam ini memiliki kemampuan beradaptasi terhadap berbagai jenis dan variasi iklim, namun begitu manusia membutuhkan peralatan tambahan untuk adaptasi lebih lama 
(Karyono, 2006). Misalnya Goa, goa bisa diartikan sebagai alat yang digunakan untuk memodifikasi iklim dengan temperatur dalam batas tolerenasi manusia yang menghuninya Dahulu kala Goa adalah bangunan rumah tinggal yang paling primitif dalam sejarah manusia. Goa dulu hanya diperuntukan untuk tempat menghindar dari hewan buas atau bahkan sekedar istrahat semasa perjalanan dan menjalani hidup yang berpindah-pindah. Mengapa goa itu ditinggali? Karena manusia sudah memodifikasi dan terbiasa dengan iklim gowa tersebut. Begitu juga apabila ditarik kedalam perkembangunan zaman sekarang misalnya rumah tinggal, kantor, hotel dan bangunan-bangunan lain dengan fungsi yang semakin berkembang. Tidak sekedar melindungi, akan tetapi juga menjadi identitas yang merekam nilai-nilai sejarah, zaman atau cerita-cerita dibalik itu. Ada faktor pembentuk bangunan itu terjadi, entah itu bangunan untuk beribadah, bangunan untuk mengenang, bangunan untuk belajar dan lain-lain. Bahwasanya bangunan selalu dirancang berdasarkan faktor-faktor penentunya. Apakah faktor penentu terbesar dalam perancangan itu? Jawaban yang paling tepat merupakan iklim setempat. Pengetahuan Tentang Iklim selalu menjadi penentu dalam keberhasilan sebuah perancanagan selalu menjadi concern leluhur-leluhur terdahulu dalam merencanakan tempat tinggalnya. Jauh sebelum kearifan lokal itu dibekukan pastilah ada percobaan yang membentuk suatu ketentuannya. Sesederhana apapun kebijakannya, wawasan iklim yang baik selalu menjadi pembentuk kearifan lokal menjadi sangat bernilai.

\section{Shading Device}

Menurut (Pemrov DKI Jakarta, 2012) bahwasanya prosentase rata-rata $55 \%$ pemakaian energi sebuah kantor dijakarta dihabiskan untuk pendingin ruangan diikuti dengan $27 \%$ pencahayaan, $4 \%$ lift dan $14 \%$ lainnya. dengan rincian rata-rata perolehan panas pada gambar 1 berikut

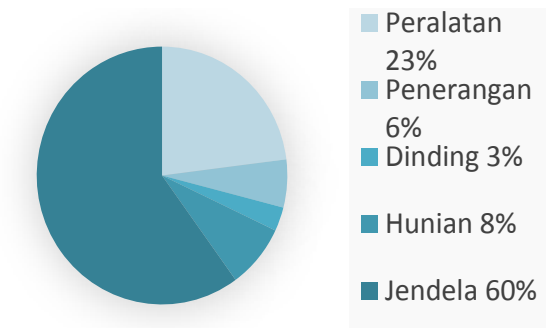

Gambar 1 Rata-rata Perolehan Panas Internal (Pemrov DKI Jakarta, 2012)

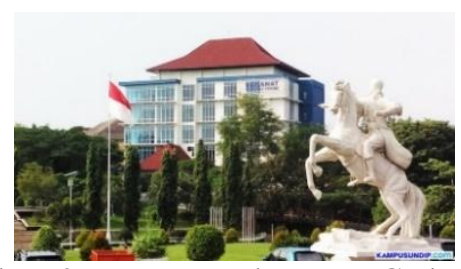

Gambar 2 Foto Tampak Depan Gedung Dekanat FT http://www.kampusundip.com/2016/04/finishingpembangunan-dekanat-fakultas.html

Berdasarkan data diatas bisa ditarik kesimpulan bahwasanya rata-rata Konsumsi Beban Pengkondisian udara dan penerangan mendapatkan porsi sekitar $82 \%$ dalam konsumsi energi suatu bangunan. Prosentase dipengaruhi oleh Pancaran Sinar dari matahari sehingga tepat adanya apabila penelitian ini berupaya menghalangi sinar matahari dari luar sehingga kondisi peluang untuk menang itu besar, bahkan sebelum pertarungan itu dimulai.

Pelaksanaan riset berada pada Ruang kerja Aset yang berada di Lantai 2 Gedung Kantor Dekanat FT Undip, Area Fakultas Teknik Universitas Diponegoro, Semarang. Gedung ini dipilih karena merupakan gedung wajah civitas teknik kampus Universitas Diponegoro (lihat gambar 2).

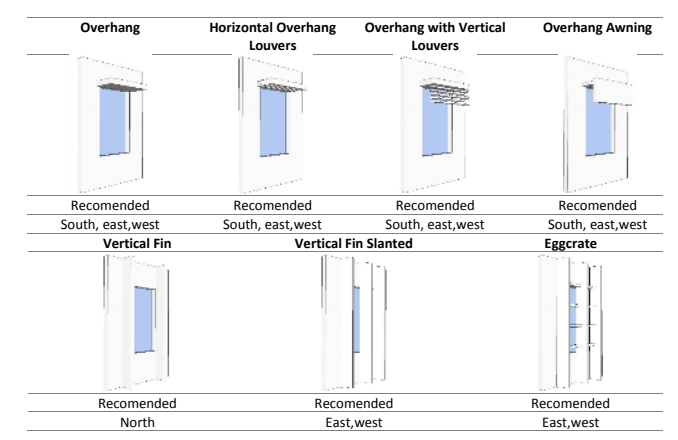

Gambar 3 Shading Device Rekomendasi Lechner

Adapun Persyaratan Shading device yang baik menurut (Norbert Lechner, 2007) adalah sebagai berikut (lihat gambar 3 untuk visualisasi),

a. Tidak Silau/ tidak Glare

b. Melindungi bangunan dari hujan

c. Mampu menghalangi atau mengurangi masuknya panas

d. Memberikan view keluar yang cukup

e. Mampu memperlancar aliran angin

f. Memenuhi estetika yang baik

g. Memastikan jumlah sinar yang masuk untuk penerangan alami

\section{METODE}

Penelitian ini menggunakan metode simulasi Autodesk ecotech dengan jenis penelitian experimental. 
Dengan langkah kerja mula- mula mengindentifikasi lokasi, arah matahari, mengukur luasan ruangan, ketinggian plapond dan luasan bukaan. Bukaan hanya satu type yakni bukaaan tinggi dan lebar seperti Tabel 2 Spesifikasi Ruangan lalu mensimulasikanya sehingga mendapatkan rekomendasi yang Optimal untuk Gedung Dekanat FT Undip ini.

Adapun langkah Prosedural Simulasi yang peneliti lakukan adalah sebagai berikut,

a. Pembuatan gambar pada software Autocad

b. Pembuatan 3d model pada software Sketchup

c. Lalu Import File ke Software Ecotect dengan format .Dxf

d. Mangatur Data Cuaca iklim kepada Kota Semarang kepada setinggan default demi mendapatkan simulasi yang paling mendekati kebenaran.

e. Selanjutnya memilih waktu dan tanggal serta kondisi langit. Dalam hal ini akan dipilih 2 tanggal Representatif puncak ekstrim iklim tropis tahunan yaitu 22 Juni dan 22 Desember.

\section{PEMBAHASAN}

Berikut Merupakan Foto-Foto (gambar 4-5) yang Peneliti ambil pada hari selasa tanggal 9 April 2019

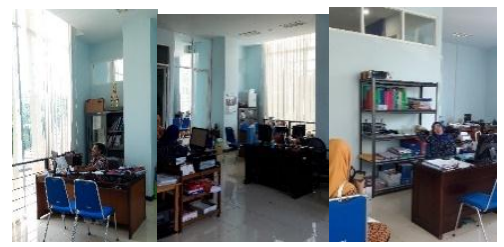

Gambar 4 Ruang Aset Dekanat FT Undip

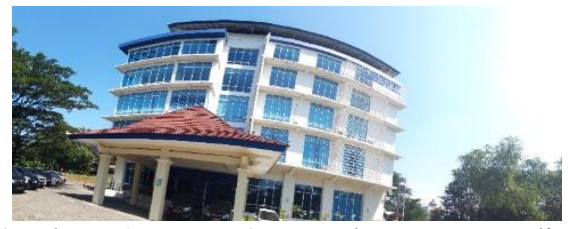

Gambar 5 Ruang Aset Dekanat FT Undip

Adapun data fisik Gedung Dekanat FT Undip yang berhasil dikumpulkan peneliti adalah orientasi bangunan (tabel 1), spesifikasi bangunan (tabel 2), pemilihan kaca (tabel 3).

Tabel 1 Orientasi bangunan

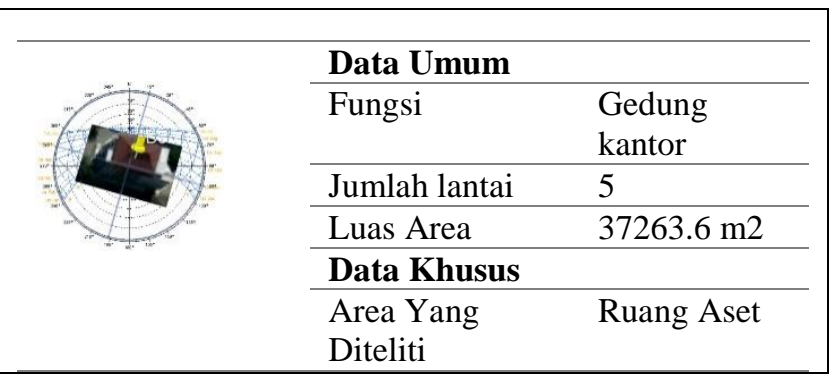

\begin{tabular}{|ll|}
\hline Luas Lantai & $78.85 \mathrm{~m} 2$ \\
\hline $\begin{array}{l}\text { Orientasi Utama } \\
\text { Bangunan }\end{array}$ & $15 \mathrm{~N}$ \\
\hline Latitude & -7.050 \\
\hline Longitude & 110.43 \\
\hline
\end{tabular}

Dari Gedung tersebut Peneliti memilih melakukan penelitian pada Ruang Aset Yang terletak pada Lantai 2 dengan spesifikasi data ruangan eksisting sebagai berikut (lihat tabel 2),

Tabel 2 Spesifikasi Ruangan

\begin{tabular}{|c|c|c|}
\hline Visualisasi & Keterangan & \\
\hline \multirow{6}{*}{ 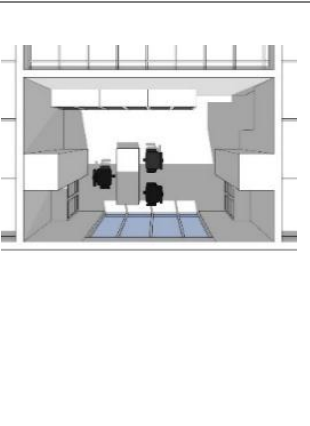 } & $\begin{array}{l}\text { Panjang } \\
\text { Ruangan }\end{array}$ & $2.64 \mathrm{~m}$ \\
\hline & $\begin{array}{l}\text { Lebar } \\
\text { Ruangan }\end{array}$ & $4.06 \mathrm{~m}$ \\
\hline & Luas lantai & $10.71 \mathrm{~m}$ \\
\hline & $\begin{array}{l}\text { Tinggi } \\
\text { Plapond }\end{array}$ & $2.75 \mathrm{~m}$ \\
\hline & $\begin{array}{l}\text { Warna } \\
\text { Dinding }\end{array}$ & Putih \\
\hline & $\begin{array}{l}\text { Warna } \\
\text { Plapond }\end{array}$ & Putih \\
\hline \multirow[t]{6}{*}{ Visualisasi } & Keterangan & \\
\hline & Panjang & $2.64 \mathrm{~m} 2$ \\
\hline & Lebar & $4.06 \mathrm{~m} 2$ \\
\hline & Tinggi & $2.64 \mathrm{~m} 2$ \\
\hline & Bahan Kaca & $\begin{array}{l}\text { Panasap } \\
\text { Dark Blue } \\
5 \mathrm{~mm}\end{array}$ \\
\hline & Bahan Kusen & $\begin{array}{l}\text { Aluminium } \\
\text { Grey }\end{array}$ \\
\hline
\end{tabular}

Adapun Material kaca yang dipakai pada gedung Dekanat FT Undip ini adalah sebagai berikut :

Tabel 3 Spesifikasi Kaca Ruangan

\begin{tabular}{clccc}
\hline No & Data Kaca & SF & Sc1 & U-Value \\
\hline 1 & $\begin{array}{l}\text { PANASAP DARK } \\
\text { BLUE }\end{array}$ & $55 \%$ & 0.63 & 5.7 \\
\hline 2 & INDOFLOT CLEAR & $85 \%$ & 0.97 & 5.8
\end{tabular}

Sumber : http://www.amfg.co.id/en/product/flatglass/brochure/

Langkah selanjutnya adalah memvalidasi orientasi riil dekanat dengan simulasi, agar proses simulasi selanjutnya sesuai dengan kondisi eksistingnya (table 4)

'Tabel 4 Validasi Orientasi

$\begin{array}{cc}\text { Orientasi } & \text { Orientasi } \\ \text { Riil } 15^{\circ} \mathrm{U} & \text { Simulasi } 15^{\circ} \mathrm{U}\end{array}$



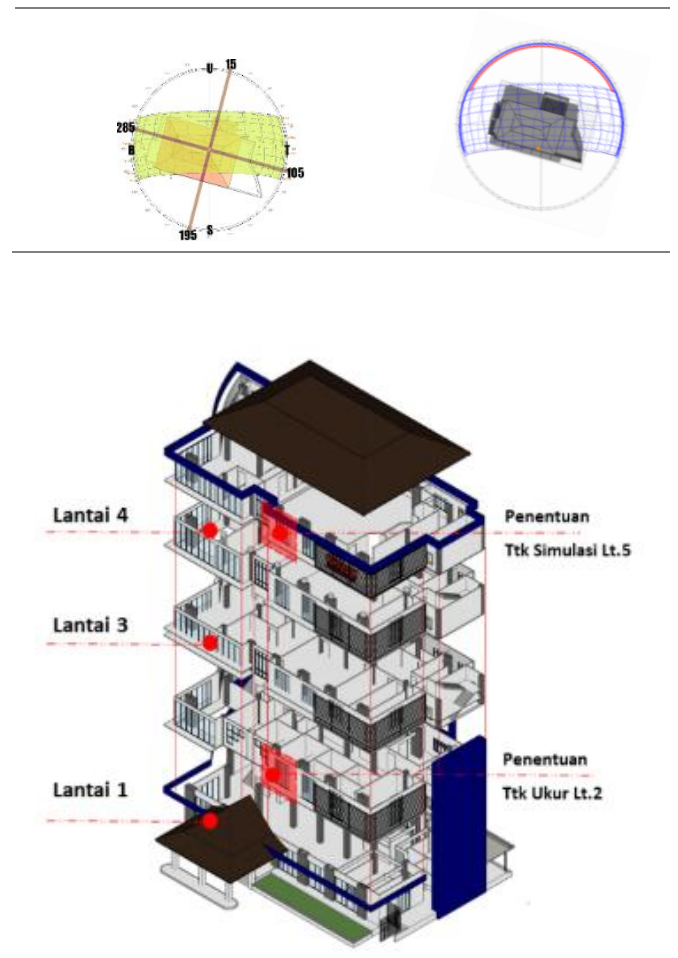

Gambar 6 Isometrik Gedung Dekanat FT Undip

Berikut Merupakan Daylighting Eksisting yang ada ada ruang aset gedung dekanat FT Undip yang diukur pada lantai 2 (lihat figure 6) yang menghasilkan simulasi berupa gambar 7 berikut.

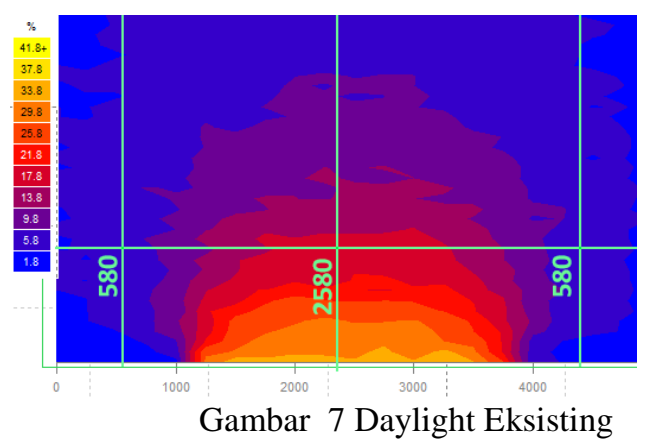

Tabel 5 merupakan simulasi pembayangan berdasarkan data iklim dan simulasi pada bulan juni dan desember yang di simulasikan dengan software ecotect untuk mendapakan gambaran keadaan ruang pengujian pada saat yang ditentukan tanpa harus melakukan pada saat tersebut.
Tabel 5 Orientasi Matahari

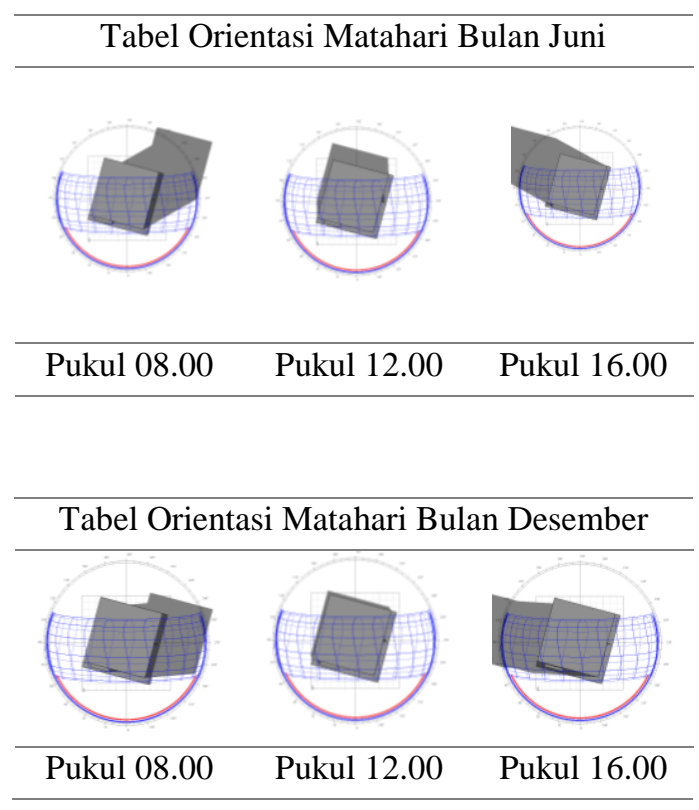

Gambar diatas

Tabel 5 Orientasi Matahari merupakan pembayangan pada gedung Dekanat FT pada bulan Juni dan Desember dimana merupakan Puncak Balik dari Posisi matahari yang mempengaruhi iklim negara indonesia Langkah selanjutkan adalah mensimulasikan bukaan terhadap tiga rekomendasi desain awal yang peneliti ambil sesuai dengan tiga shading devices yang direkomendasikan sesuai tabel 6 dan 7 (Badan Standarisasi Nasional, 2000) demi menghalau sinar matahari yang berlebih masuk kedalam ruangan dengan kode acuan sebagai berikut

1. Shading Device 1 (SD1/ Overhang)

2. Shading Device 2 (SD2/ Vertical Pin)

3. Shading Device 3 (SD3/ Eggcrate)

Tabel 6 Kondisi Pembayangan Bulan Juni

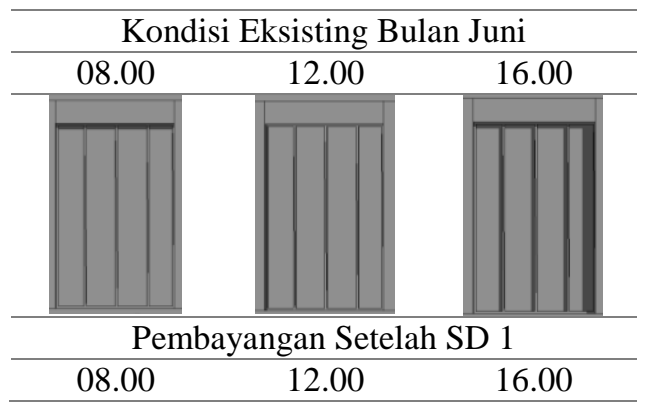




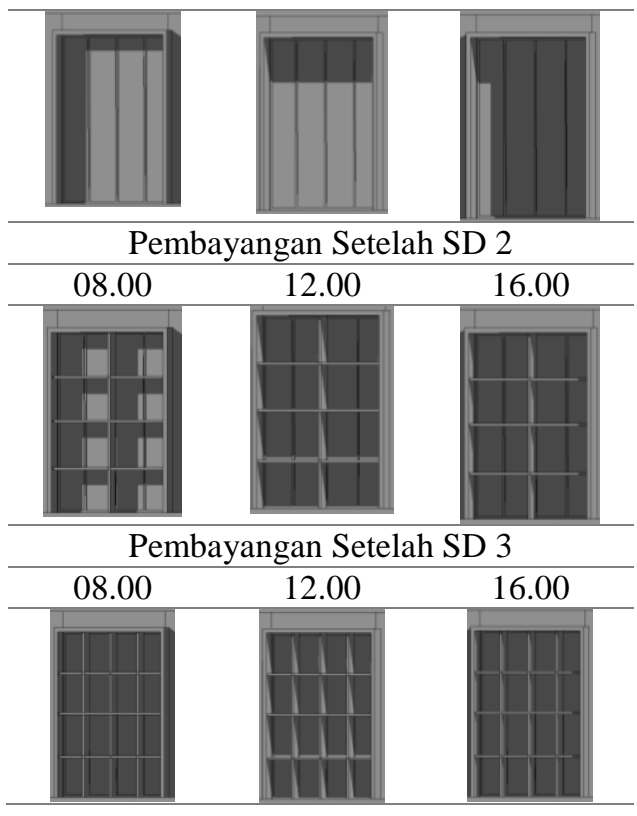

Tabel 7 Kondisi Pembayangan Bulan Desember

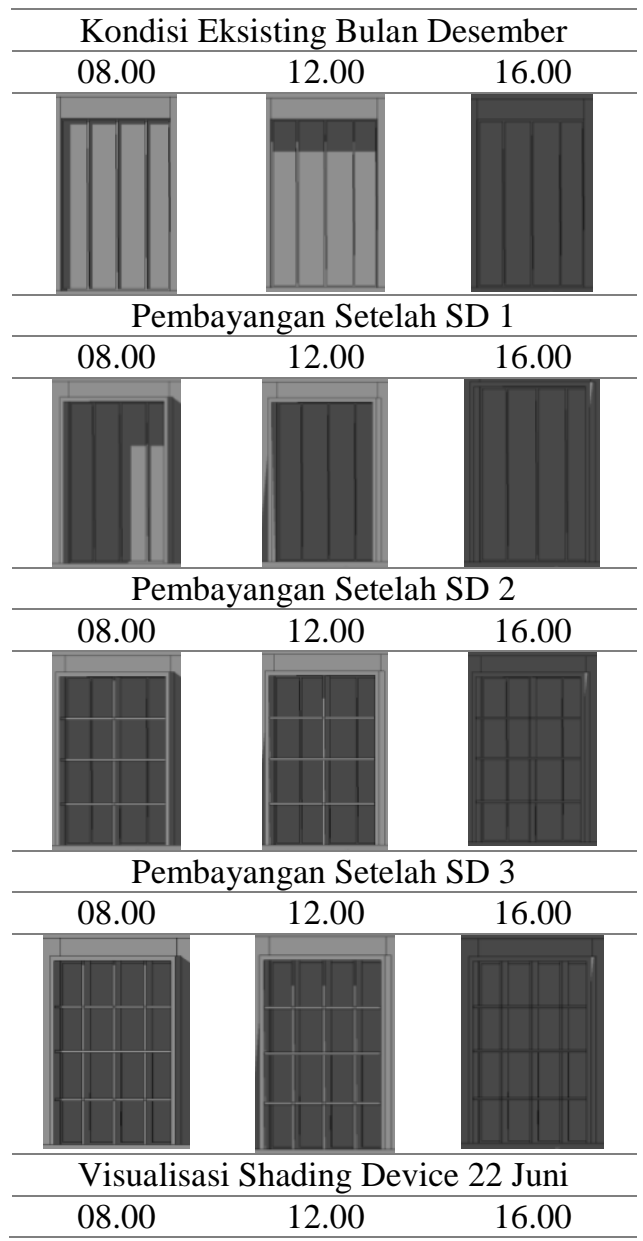

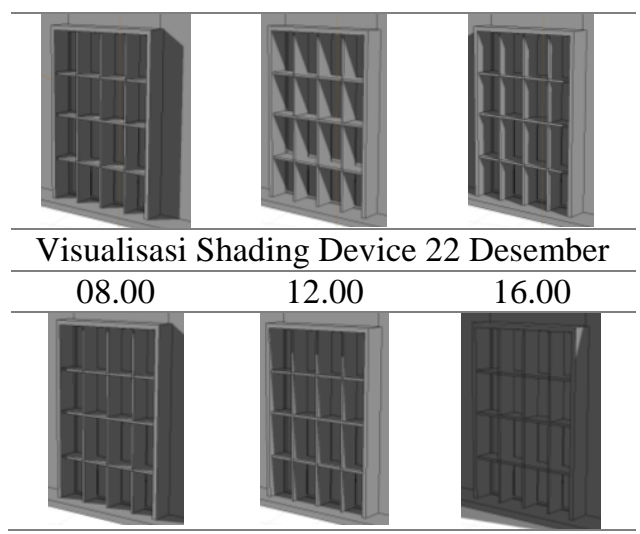

Selanjutnya peneliti mensimulasikan bagaimana nilai kinerja SD3 terhadap daylight ruang Aset, sehingga dihasilkan nilai pada simulasi gambar 8 .

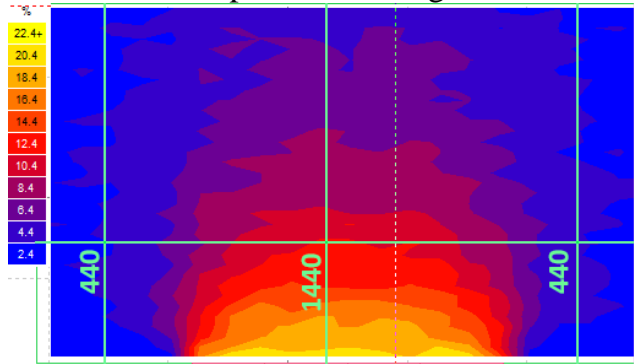

Gambar 8 Simulasi Daylighting SD3

Walaupun kinerja SD3 ini telah berhasil menurunkan perolehan sinar matahari sebsar 30\% Karena bentuk daripada SD3 tidak memenuhi kriteria d,e, dan f) sehingga peneliti mencari alternatif kembali mencari shading device yang sesuai dengan tanpa mengurangi performa kinerjanya. Tabel selanjutnya merupakan 6 alternatif pengganti SD3 dengan kode acuan sebagai berikut (lhat tabel 8)
1. Shading Device a / SDA
2. Shading Device b/ SDB
3. Shading Device c/ SDC
4. Shading Device d/ SDD
5. Shading Device e/ SDE
6. Shading Device $\mathrm{f} / \mathrm{SDF}$

Tabel 8 Simulasi Daylighting Berbagai Alternatif

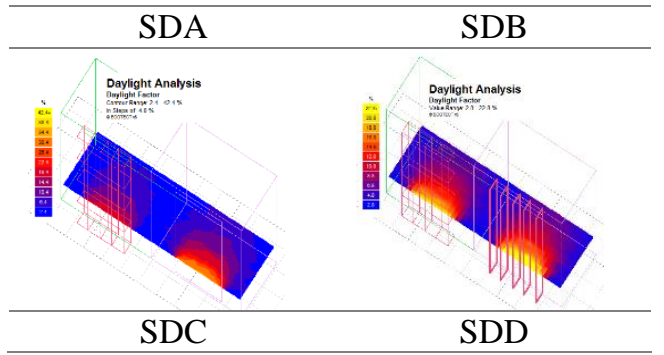




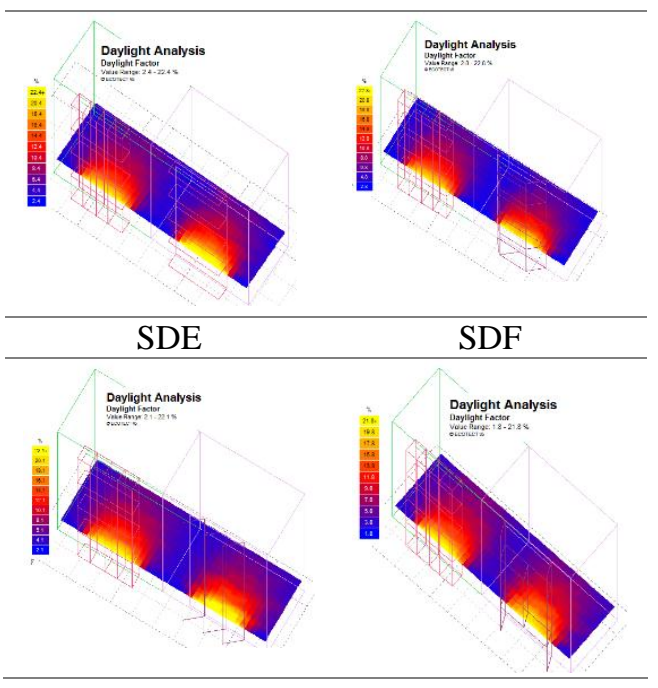

Sehingga didapat SDF dipilih sebagai pengganti SD3 dengan keunggulan spesifikasi seperti table 9 berikut.

Tabel 9 Perbandingan Daylighting Alternatif terpilih

Perbandingan SD3 dengan Kondisi Eksisting

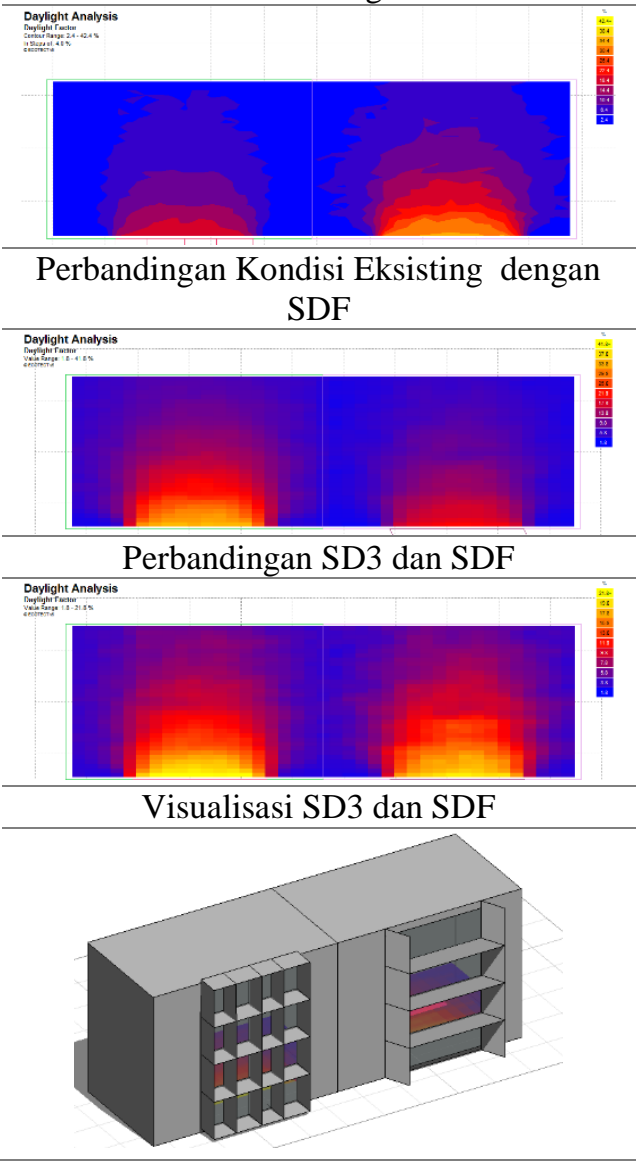

Gambar 9 dan 10 dibawah menunjukan nilai daripada daylight SDF yang berhasil menurunkan ratarata $36 \%$ cahaya matahari yang masuk dibandingkan dengan kondisi sebelumnya (Gambar 8 Simulasi Daylighting SD3)

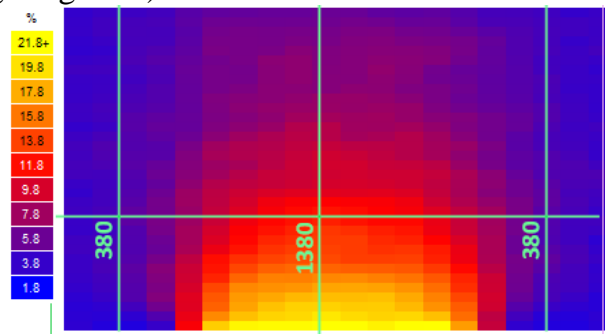

Gambar 9 Nilai Daylighting Shading Device F

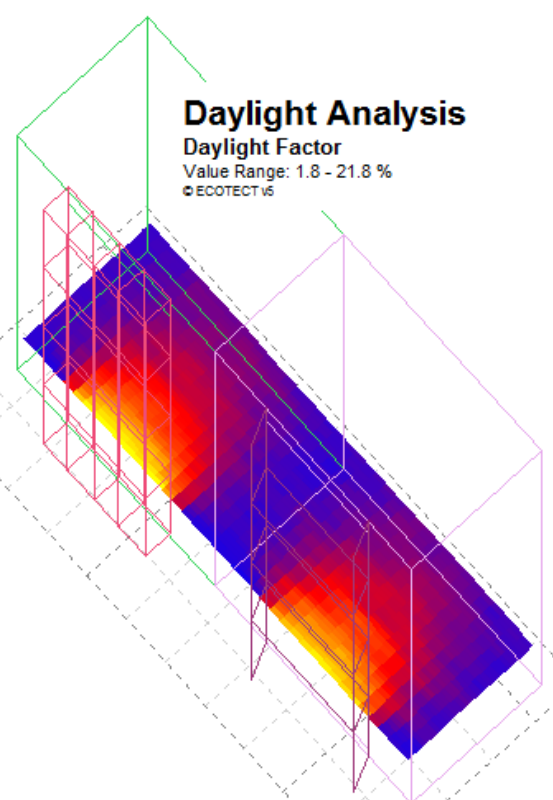

Gambar 10 Perbandingan Shading Device 3 dan F

\section{KESIMPULAN}

Desain eggcrate banyak hal cara yang bisa ekspolasi kembali dalam proses arsitektur. Ketentuan Teori sebaiknya bukan dijadikan dalam halangan dalam mengekspolasi bentuk akan tetapi dijadikan peluang dalam pengekspolasi yang lebih baik dan terukur. Kinerja SD3 bisa menurunkan rata-rata 30\% perolehan sinar matahari sedangkan Kinerja Shading F berhasil menurunkan sebesar rata-rata $38 \%$ dari perolehan panas akibat matahari dengan desain yang lebih baik dan penggunaan material yang lebih sedikit dibandingkan dengan SD 3. Menurunan perolehan panas ini berpotensi membantu kinerja pendinginan udara . Perancangan Desain Shading device dalam konteks bangunan juga sangat krusial karena menghiasi seluruh fasade sehingga perlu kehati-hatian dalam penentuan keputusannya. 


\section{Ucapan Terimakasih}

Kepada Bapak Bayu Kepala Aset Gedung Dekanat Fakultas Teknik yang memberi akses penuh dalam Pengukuran dan Ibu Mahdalena Risnawaty yang Mensupport penuh Alat pengukuran hingga selesainya penelitian ini.

\section{REFERENSI}

Badan Standarisasi Nasional. (2000). Konservasi energi selubung bangunan pada bangunan gedung. 1., 139. Diambil dari http://www.bsn.go.id/main/berita/berita_det/8362

Baharuddin. (2011). Aplikasi Simulasi Komputer Dalam Upaya Meningkatkan Pencahayaan Alami Bangunan. Hasil Penelitian Fakultas Teknik, 5(Group Teknik Arsitektur), 978-979.

Hamzah, B., Arsitektur, J., Teknik, F., Makassar, U. M., Arsitektur, J., Teknik, F., \& Hasanuddin, U. (2014). Pengaliran Udara Untuk Kenyamanan Termal Ruang Kelas Dengan Metode Simulasi CFD, 14(2), 209-216.

Karyono, T. H. (2006). ANTISIPASI ARSITEK DALAM MEMODIFIKASI IKLIM MELALUI KARYA. Jurnal Sains dan Teknologi EMAS, (July).

Maulana, S. (2016). PEMANFAATAN COMPUTATIONAL FLUID DYNAMICS ( CFD ) DALAM STRATEGI PENELITIAN SIMULASI MODEL, 2, 10-13.

Norbert Lechner. (2007). HEATING COOLING LIGHTING, Sustainable Design Methods for Architects. PT.Rajagrafindo Persada, Jakarta,.

Pemrov DKI Jakarta. (2012). Panduan Pengguna Bangunan Gedung HIjau Jakarta (Vol. 1). jakarta. Diambil dari https://greenbuilding.jakarta.go.id/

Pribadi, S. B., \& Indarto, E. (2002). Ketepatan Orientasi Gedung Ict Undip, 1-8.

Satwiko, P. (2011). Pemakaian Perangkat Lunak Dialux Sebagai Alat Bantu Proses Belajar Tata Cahaya. Komposisi, 9, 142-154. 